\title{
PREMATURE OVARIAN INSUFFICIENCY - TO TREAT OR NOT TO TREAT?
}

\author{
LITERATURE REVIEW
}

\section{O.S. ZAHORODNIA \\ MD, associate professor of the Obstetrics and Gynecology Department №1, 0.0. Bogomolets National Medical University, Kyiv ORCID: 0000-0003-0424-8380 \\ I.B. VENTSKIVSKA \\ MD, professor, head of the Obstetrics \\ and Gynecology Department №1, \\ 0.0. Bogomolets National Medical University, Kyiv \\ ORCID: 0000-0002-7685-5289 \\ A.V. KAZAK \\ $\mathrm{PhD}$, associate professor of the Obstetrics and Gynecology \\ Department №1, 0.0. Bogomolets National Medical University, Kyiv ORCID: 0000-0002-8248-1539 \\ Contacts: \\ Iryna B. Ventskivska \\ Kyiv Perinatal Centre \\ Predslavinska str. 9 \\ 03150 Kyiv, Ukraine \\ phone: + 38 (044) 5228748 email: gyner2007@gmail.com}

\section{INTRODUCTION}

Premature ovarian insufficiency (POI) is a rare, but very damaging lifestyle condition, that occurs at 1-1.5 of women [1] and means termination of menstrual function up to 40 years old. POI impact on women's wellbeing includes lipid metabolism dysregulation, haemostasis regulation changes, both leading to heart diseases risk increasing, psychological problems, based on early reproductive function termination and anxiety because possible sexual dysfunction, manifestation of pelvic floor disorders [2]. Patients with POI have symptoms similar to other women in menopause, namely vegetative nerve system disorders (hot flashes, night sweats, and emotional lability), insomnia and sexual dysfunction due to vaginal dryness, dyspareunia, and libido loss. It is believed that estrogen and progesterone deficiency is a leading reason of these complains, but in the same time the role of testosterone decreasing is discussed.

Estrogens whenever are the most studied and controversial hormones in the medical literature and in the medical community. Use of exogenous estrogens over the past 70 years has been so widely welcomed and denied that most professionals today have no firm opinion on their efficacy and safety [3]. When assigning female sex hormones we should remember the peculiarities of their kinetics. Most estrogens in the systemic bloodstream are bound to a specific transport protein - sexual steroid binding globulin, and only small portion is circulating as a free fraction. Increasing the sexual steroid binding globulin lead to decreases the hormone bioavailability to the tissues and its release provokes increased bioavailability of the hormones. The place of formation of the transport protein is the liver both exogenous and endogenous factors influence its rate of its excretion. It is stimulated by estrogen itself (including exogenous, so it is sometimes difficult to predict the treatment effect on target tissues), thyroid hormones, prolonged stress, aging and digestive disorders. At the same time excess body weight, increased concentration of prolactin and androgens, and uptake of progestins inhibit the excretion of transport protein [4].

R. Wilson and T. Wilson in 1963 were the first who argued for the prescription of estrogenic drugs to prevent the aging of a woman and maintain her somatic health [5]. Since then, more than 2 dozen large-scale studies have been devoted to the issue, including the Heart and Estrogen/Progestin Replacement Study (HERS) [6], the Women's Health Initiative (WHI), the Kronos Early Estrogen Prevention Study (KEEPS) [7], Early versus Late Intervention Trial with Estradiol (ELITE) [8], Study of Women's Health Across the Nation (SWAN) [9]. The results obtained were confirmed in experiments on animals, mainly human apes. Besides other aspects it has been demonstrated that the estrogens administration after menopause does not have a positive effect on the progression of atherosclerosis, while their use at a younger age is effective in terms of prognosis [10].

\section{POI AND HORMONAL \\ REPLACEMENT THERAPY}

Currently, the main source of information on the effectiveness and safety of hormonal replacement therapy (HRT) is the data from the WHI study. The bursting effect of the bombshell has been informed that HRT not only does not prevent majority of cardiovascular disease as a consequence of estrogen deficiency, but increases the risk of stroke, coronary heart disease and malignant tumors [11].

Unfortunately or unluckily these data are difficult to translate into the early menopausal women population, since the study was conducted in postmenopausal elderly women. There is deficiency of estrogen hormones in women with $\mathrm{POI}$, it is not a physiological but a pathological condition, so the appointment of exogenous estrogens is more appropriate for the name of replacement therapy, because they compensate for the level of hormones that their healthy peers have [12].

Speaking accurately, therapy with exogenous estrogens for women with $\mathrm{POI}$ is really replacement, while for patients with normal age menopause it is rather therapy of extension. Nevertheless, only $52 \%$ patients with POI have discussed it with their doctors [13].

\section{Cardiovascular disorders}

Although we do not have powerful evidences of HTR effectiveness for heart and vascular diseases prevention in women with POI (that is because absence of actual long-term observation), 
the main pathogenic reasons of its development are similar and even more aggressive. The non-medical ways of cardiovascular risk reduction are considered weight control, management of lipid profile and arterial hypertension [12].

\section{Menopausal symptoms}

Numerous studies have resulted in recommendations from the US Food and Drug Administration for the feasibility of prescribing HRT only for vasomotor and urogenital symptoms of menopause [14]. Question of the timing of the HRT appointment remains unclear.

HRT effectiveness of in POI has been demonstrated in women with artificial cessation of menstrual function (bilateral ovariectomy or chemotherapy). Thus the HRT use in women who have had bilateral oophorectomy has been proved to reduce the incidence of hot flashes by up to $20 \%$ compared with $41 \%$ in women not taking exogenous estrogens [15].

Piccioni et al. (2004) analyzing the health status of women who have discontinued menstrual function due to cancer chemotherapy and found that $66 \%$ of HRT group participants reported a significant reduction in the frequency and severity of hot flashes, insomnia, and emotional lability [16].

Bentti-Punto et al. (2015) studied the effect of estrogen replacement therapy on the microflora and trophic state of vaginal epithelium, sexual function of women with early menopause, comparing them with women with persistent menstrual function. It has been shown that despite the absence of significant differences in the composition of the microbial landscape, the frequency of fungal infection, vaginal $\mathrm{pH}$, women receiving hormone replacement therapy due to premature termination of ovarian function have a lower quality of sex life than their peers, mainly due to pain and decreased moisture [17].

\section{Urodynamic disorders}

Efficacy of estrogen replacement therapy for urodynamic disorders in premature menopause has been little studied. The only available publication in this regard is dated 1989, dedicated to an instrumental study of urodynamics in 6 women 36-42 aged with discontinued ovarian function. Indicator studies were performed prior to initiation of hormone replacement therapy and after 6 and 12 months of administration. No significant differences were found in the indices, which gave the authors reason to argue that exogenous progesterone preparations alone are not sufficient for the prevention and treatment of urodynamic disorders in women with POI [18].

Similarly the HRT effectiveness in improving the quality of sex life has not been proven. Pacello et al. (2014) have even shown that women receiving systemic hormone therapy due to premature ovarian depletion report even worse quality of sexual life than their healthy peers [19].

\section{Emotional disorders}

Emotional disorders by $\mathrm{POI}$ are not life-threatening, but much decreasing the quality of life. The risk of significant depression is higher among women with menopause before 40 years and controversy to depression at women with in-time menopause, does not depend on marriage status, whether or not she had children, social status [20]. There are dates about correlation of depression risk with severity of vegetative symptoms. Controversies in question of hormone treatment of depression, induced by early menstrual function termination, are based on lack of its effectiveness, proved by placebo-control investigations. One of such study accents, that for comparing of HRT effectiveness with placebo is possible only after endocrine confirmation of POI and by early start of treatment. It was one of the first discoveries about POI and its treatment, that natural estrogens in a continuous regime are effective to relieve or stop depression and other psychological disorders in this patients group [12]. It is also discussed if androgen addition to this scheme may increase the effectiveness, but actually results argue that this has any influence on quality of life and mood of patients.

\section{Osteoporosis}

A special indication to HRT prescription, not depending on menopause age, is an increased family risk of osteoporosis. Almost all studies, devoted to the benefits and disadvantages of HRT, certify the positive influence of therapy on osteoporosis development. The POI is not exclusion. Beyond this the density of bone tissue is getting its peak only at the age near to 30 years, and the menstrual function termination not long after this age or even before it is very dangerous.

Popat et al. (2014) reported about the results of 3-year study that included 145 women with menopause before 45 years and 70 healthy women of the age 40-45. [21]. Women with menopause were randomized on getting transdermal estrogens and medroxyprogesterone acetate combination and the same combination plus testosterone. At the beginning of study patients with menopause demonstrated a lower bone density of femoral neck then healthy women, but with currency of study the indicators of control group were decreasing and increasing in main group. So in the end of the study the authors certified similar data of bone mineral density in both groups. In the same time they noticed that additional testosterone receiving leads to more significant bone mineral density increasing in three years of treatment [22].

Comparing of HRT regimen and combined oral contraceptives the replacement therapy is more effective from the point of view bone fractures [23]. Authors, dealing with a problem of osteoporosis in menopause, accent the importance of aggressive POI diagnostic from positions of bone mineral density loss, usually missed by doctors and patients, by discussing possible reasons of menstrual delay instead of follicle stimulating hormone (FSH) concentration test. This delay leads to a quick and significant increasing of bone fracture risk [24].

There are also nonhormonal ways of osteoporosis prevention, among them vitamin D and calcium adequate intake. Popat at al. (2009) demonstrated that 58\% patients with POI have inadequate daily vitamin D intake, and 49\% - calcium. The range of vitamin $D$ that should be maintained at women with POI is $30 \mathrm{ng} / \mathrm{ml}$ and a daily intake of vitamin D is 1000-2000 IU and $1200 \mathrm{mg}$ of elementary calcium. At the same time an adequate level of physical training also very important for bone fractures prevention. It was also noticed that women of all races, except white, have an increased risk of osteoporosis [24]. 


\section{Cognitive function}

Estrogen deficiency is harmful not only for vessels, heart and bones, but also for cognitive function. Neuroprotective effect of exogenous estrogens is demonstrated by animal experiments, it includes enhancing of synaptic plasticity and reducing of $\beta$-amyloid production that is a morphological signs of Alzheimer disease [25]. The human observations confirm that HRT with estrogens improves brain activity, especially speaking about memory [26]. Other studies accent, that the earlier it the start of HRT from the time of menopause, the better are its results [27]. Unfortunately, all mentioned studies deal with the whole postmenopause women cohort, but not with POI patients. We can confirm the HRT necessity for cognitive function improving at patients with POI only by extrapolation of these studies.

\section{Infertility}

A unique problem that makes difference between patients with $\mathrm{POI}$ and other postmenopausal patients is infertility. The "shocked" status proper to patients with POI in most cases is explained by a realizing of reproductive function termination. But according to J. van Kastereh $5-10 \%$ of POI patients and 46XX genotype get spontaneous pregnancy [28]. Speaking of early menopause pathogenesis it is rather ovarian inability to react on stimulating factors, then lack of oocytes. The tonic increased level of luteinizing hormone leads to follicule luteinization before it has grown enough for maturity. That's why, in theory, physiological estrogen intake regimes may interrupt this cycle and make ovary more sensitive both to endogenous and exogenous stimulating factors. Besides this, an increased FSH is believed to down-regulate the FSH-receptors in granulose cell. HRT may lead to FSH-receptors restoration and thus to possibility of effective foliculle stimulation [29].

Despite so rich theoretic explanation controlled trials did not demonstrate such optimism. One of them, basing on $2 \mathrm{mg}$ of ethinylestradiol orally per day revealed significant suppression of luteinizing hormone, but no positive impact on folliculogenesis and pregnancy rate [30]. In the same time other study compared effectiveness ovulation stimulation with previously 6-weeks administration of 0.05 ethinylestradiol per day and placebo. Frequency of successful stimulation by first scheme was $32 \%$ higher. By the way, the authors noticed that follicular development and ovulation were possible only after FSH level achieved $15 \mathrm{mU} / \mathrm{ml}$ [31]. Nevertheless, the possible earliest HRT start makes it also more effective from the point of view reproductive plans too.

\section{Dry eye syndrome}

Another specific complication of POI is a dry eye syndrome. Frequency of this syndrome among women with early menstrual function termination reaches $20 \%$, comparing with $3 \%$ in general population. The mechanism of its development is not associated with reduced tear production, as it is proper to elder patients. Smith et al. (2004) proved expression of sex-steroid on the surface of ocular tissues, but they speak about androgen deficiency as a leading course of dry eye syndrome at patients with POI. Accordingly, there have not been conducted studies about HRT effectiveness for this problem management [32].

\section{Hot flashes}

Separately hot flashes as a sign of climacteric syndrome should be mentioned in a complex of problems, touching a woman with POI. The effectiveness of HRT for hot flashes treatment is proved only for cohort of patients with artificial early menopause. There are any trials, devoted to HRT effectiveness for hot flashes by spontaneous POI [33].

\section{CHOICE OF HRT TYPE}

Speaking about perfect way of estrogen administration, we cannot be sure. According to idea of replacement, the best decision will be a creature of artificial ovarian that will produce estrogens, according to natural cycle. Transdermal patch and vaginal ring were first steps in this direction. Both of them lead to serum estrogen concentration about $100 \mathrm{pg} / \mathrm{ml}$, that is close to average concentration in normal menstrual cycle [34]. Moreover, administration of these forms let to avoid main side effects, associated with liver passing, whereas they deliver hormone directly to circulation. The main of them is an increasing risk of venous thromboembolism. According to Canonico et al (2007) relative risk of this complicating by use of oral estrogens comparing with placebo is 4.2 and by transdermal estrogen delivery is 0.9 [35].

Dealing with patients of active reproductive age, from the point of view to imitate menstrual function, the idea of oral contraceptive use was discussed. These drugs contain a synthetic hormone, which provides supraphysiologic concentration of estrogen in circulation. It has negative influence on thromboembolic and heart diseases risk, lipid profile changes. As well, this regime provides a pill-free week, monthly or once a three months, what in $\mathrm{POI}$ patients can result negative menopausal symptoms [36]. Langrish et al. (2009) in randomized controlled trail compare cardiovascular effects of transdermal HTR and oral contraceptives. After 12 months in HRT group more favorable changes in blood pressure, renal function and rennin-angiotensin-aldosterone system were registered [37].

Patients with $\mathrm{POI}$ have an intact uterus in majority of cases, so any exogenous estrogen administration should be accompanied by progestin. Among numerous progestins only medroxyprogesterone acetate produce proper to normal menstrual cycle secretory transformation of endometrium. By administration on cyclic regime it may result endometrium hyperplasia. Comparing with other progestins, this one does not have androgenic side effects, because its molecule is not derived from testosterone [38].

\section{OTHER TYPES OF THERAPY}

Traditionally, lifestyle modification is recommended to alleviate menopausal syndrome, including smoking cessation. Researchers point to the rather low effectiveness of such recommendations [39]. Numerous methods of psychotherapy have been proposed for the normalization of the psychological state - techniques of cognitive-behavioral therapy, gestalt therapy, psychodrama [40]. Despite the described influence not only on the central nervous system, but also indirect regulation of the function of the autonomic nervous system, the authors of these methods insist on their high efficiency only in mild forms of the climacteric syndrome. 
In contraindications to hormone therapy there are alternative ways to alleviate urogenital symptoms and sexual disorders. These include vaginal mucous membranes and moisturizers (water or silicone) [41]. An important role belongs to the training of the pelvic floor muscles, especially in terms of stress urinary incontinence and dysuria [42].

Lifestyle normalization and diet therapy should be recommended for all women who have early cessation of menstrual function, regardless of their contraindications or their adherence to HRT. $1000 \mathrm{mg}$ calcium and 800 IU vitamin D daily intake help to prevent or reduce the severity of cardiovascular diseases. It is recommended to quit smoking, limit alcohol and caffeine. Non-hormonal therapy is relevant only in the aspect of reducing the severity of vasomotor symptoms (serotonin and norepinephrine reuptake inhibitors), including against the HRT background. There is no evidence of herbal medicines effectiveness in the treatment or prevention of menopausal symptoms. Bisphosphonates as a means of preventing osteoporosis are contraindicated in women who have reproductive plans because they have a long half-life and unexplored effect on the fetus [43].

Tommaselli et al. (2006) studied the tibolone efficacy, an estrogen receptor agonist, against weight gain and associated lipid dysfunction [44]. Comparing the total mass of adipose tissue, the mass of abdominal fat and their ratio at the beginning of treatment and after 12 months of therapy, they concluded that the use of this group of drugs can effectively prevent the growth of adipose tissue in postmenopausal women.
Among the non-hormonal methods of correction of menopausal symptoms are described daily tranquilizers, justifying their positive effect on the course of asthenic syndrome, the ability to improve sleep and performance. Antidepressants in addition to reducing the manifestations of anxiety and depression have the ability to normalize vegetative status. Anxiolytics provides improved sleep, concentration and attention [45].

It is important treatment of primary disease that caused the POI. Thus the recovery of ovarian function in patients with celiac disease has been described following a gluten-free diet [46]. A positive effect was obtained from the use of immunomodulation therapy to stimulate ovulation (high doses of corticosteroids and intravenous administration of immunoglobulin). Restoration of ovarian function occurs in patients with severe myasthenia gravis after thymectomy. Attempts have been made to use monoclonal antibodies in the treatment of autoimmune ovarian insufficiency. Melatonin is a perspective factor in influencing ovarian and thyroid function [47].

\section{CONCLUSION}

There is no doubt that POI significantly worsens a woman's quality of life and thus needs adequate and effective therapy. But there is no consensus in the scientific world as to the optimal POI treatment, although there is consensus on its necessity and duration until the onset of physiological menopause.

\section{REFERENCES/ЛІTЕPATУPA}

\section{Okeke, T.C., Anyaehie, U.B., Ezenyeaku, C.C. \\ "Premature Menopause." Ann Med Health Sci Res 3.1 (2013): 90-95. doi: $10.4103 / 2141-9248.109458$ \\ 2. Венцківська, І.Б. \\ Раннє припинення менструальної функції: сучасні погляди на \\ патогенез та наслідки / І.Б. Венцківська, О.С. Загородня, \\ Т.Т. Наритник // Репродуктивна ендокринологія. - 2019 . \\ №4 (48). - - C. 8-12. \\ Ventskivska, I.B., Zahorodnia, O.S., Narytnyk, T.T. \\ "Early cessation of menstrual function: current views on pathogenesis and consequences." Reproductive Endocrinology 4.48 (2019): 8-12. \\ Keaney, J.J., Solomon, C.G. \\ "Postmenopausal hormone therapy and atherosclerosis: time is of the essence." N Eng J Med 374 (2016): 1279-80. \\ 4. Bhagavan, N.V. \\ Medical Biochemistry. 4 edition. Harcourt. Academic Press (2002):}

$1060 \mathrm{p}$.

5. Wilson, R.A., Wilson, T.A.

"The fate of the nontreated postmenopausal woman: a plea for the maintenance of adequate estrogen from puberty to the grave." J Am

Geriatric Soc 11 (1963): 347-62.

6. Writing Group for the Women's Health Initiative Investigators.

"Risk and benefits of estrogen plus progestin in healthy menopausal women: principal results from the Women's Health Initiative

randomized control trial." JAMA 288 (2002): 321-33.

7. Harman, S.K., Black, D.M., Naftolin, F., et al.

"Arterial imaging outcomes and cardiovascular risk factors in recently menopausal women: a randomized trial." Ann Intern Med 161 (2014)

249-60.

8. Hodis, H.N., Mack, W.J., Henderson, V.W., et al.

"Vascular effects of early versus late postmenopausal treatment with estradiol." N Engl J Med 374 (2016): 1221-31.

9. Avis, N.E., Crawford, S.L., Greendale, G., et al.

"Duration of menopausal vasomotor symptoms over the menopause transition." JAMA Intern Med 175 (2015):531-9.
10. Mikkola, T., Clarkson, T.

"Estrogen replacement therapy, atherosclerosis, and vascular function." Cardiovascular Research 53.3 (2002): 605-19. doi: 10.1016/

S0008-6363(01)00466-7

11. Rossouw, J.E., Anderson, G.L., Prentice, R.L., et al.

"Risks and benefits of estrogen plus progestin in healthy postmenopausal women: principal results From the Women's Health Initiative randomized controlled trial." JAMA 288 (2002): 321-33.

12. Sullivan, S., Sarrel, P., Nelson, L.

"Hormone replacement therapy in young women with primary ovarian insufficiency and early menopause."Fertil Steril 106.7 (2016): 1588-99.

13. Hipp, H.S., Charen, K.H., Spencer, J.B., et al,

"Reproductive and gynecologic care of women with fragile X primary

ovarian insufficiency (FXPOI)."Menopause 23 (2016): 993-9.

14. Turner, R., Kerber, I.

"A theory of eu-estrogenemia: a unifying concept." Menopause 24.9

(2017): 1086-97.

15. Madalinska, J., van Beurden, M., Bleiker, E., et al.

"The impact of hormone replacement therapy on menopausal

symptoms in younger high-risk women after prophylactic sal pingooophorectomy."J Clin Oncol 24 (2006): 3576-82.

16. Piccioni, P., Scirpa, P., D'Emilio, l., et al.

"Hormonal replacement therapy after stem cell transplantation."

Maturitas 49 (2004): 327-33.

17. Benetti-Pinto, C., Laguna, C., Giraldo, P., et al.

"Vaginal epithelium and microflora characteristics in women with premature ovarian failure under hormone therapy compared to

healthy women." Archives of Gynecology and Obstetrics 292.1 (2015): $159-64$.

18. Karram, M.M., Yeko, T.R., Sauer, M.V., Bhatia, N.N.

"Urodynamic changes following hormonal replacement therapy in women with premature ovarian failure." Obstet Gynecol 74 (1989): 208-11.

19. Pacello, P.C.C., Yela, D.A., Rabelo, S., et al.

"Dyspareunia and lubrication in premature ovarian failure using hormonal therapy and vaginal health." Climacteric 17 (2014): 342-7.
20. Guerrieri, G.M., Martinez, P.E., Klug, S.P., et al.

"Effects of physiologic testosterone therapy on quality of life, selfesteem, and mood in women with primary ovarian insufficiency." Menopause 21 (2014): 952-61.

21. Popat, V.B., Calis, K.A., Vanderhoof, V.H., et al.

"Bone mineral density in estrogen-deficient young women." J Clin Endocrinol Metab 94 (2009): 2277-83.

22. Popat, V.B., Calis, K.A., Kalantaridou, S.N., et al.

"Bone Mineral Density in Young Women with Primary Ovarian Insufficiency: Results of a Three-Year Randomized Controlled Trial of Physiological Transdermal Estradiol and Testosterone Replacement." The Journal of Clinical Endocrinology \& Metabolism 99 (214): $3418-26$.

23. Cartwright, B., Robinson, J., Seed, P.T., et al.

"Hormone replacement therapy versus the combined oral contraceptive pill in premature ovarian failure: a randomised controlled trial of the effects on bone mineral density." J Clin Endocrinol Metab 101 (2016): 3497-505.

24. Leite-Silva, P., Bedone, A., Pinto-Neto, A.M., et al. "Factors associated with bone density in young women with karyotypically normal spontaneous premature ovarian failure." Arch Gynecol Obstet 280 (2009): 177-81.

25. Maki, P.M., Resnick, S.M.

"Effects of estrogen on patterns of brain activity at rest and during cognitive activity: a review of neuroimaging studies." Neuroimage 14 (2001): 789-801.

26. Morrison, J.H., Brinton, R.D., Schmidt, P.J., Gore, A.C. "Estrogen, menopause, and the aging brain: how basic neuroscience can inform hormone therapy in women." J Neurosci 26 (2006): 10332-48.

27. LeBlanc, E.S., Janowsky, J., Chan, B.K., Nelson, H.D. "Hormone replacement therapy and cognition: systematic review and meta-analysis." JAMA 285 (2001): 1489-99.

28. van Kasteren, Y.M., Schoemaker, J.

"Premature ovarian failure: a systematic review on therapeutic interventions to restore ovarian function and achieve pregnancy." Hum Reprod Update 5 (1999): 483-92. 
29. Tartagni, M., Cicinelli, E., de Pergola, G., et al.

"Effects of pretreatment with estrogens on ovarian stimulation with gonadotropins in women with premature ovarian failure: a randomized, placebo-controlled trial." Fertil Steril 87 (2007): 858-61. 30. Taylor, A.E., Adams, J.M., Mulder, J.E., et al.

"A randomized, controlled trial of estradiol replacement therapy in women with hypergonadotropic amenorrhea." J Clin Endocrinol Metab 81 (1996): 3615-21.

31. Tartagni, M., Cicinelli, E., de Pergola, G., et al.

"Effects of pretreatment with estrogens on ovarian stimulation with gonadotropins in women with premature ovarian failure: a randomized, placebo-controlled trial." Fertil Steril 87 (2007): 858-86.

32. Smith, J.A., Vitale, S., Reed, G.F., et al.

"Dry eye signs and symptoms in women with premature ovarian

failure." Arch Ophthalmol 122 (2004): 151-6.

33. Podfigurna-Stopa, A., Czyzyk, A., Grymowicz, M., et al.

"Premature ovarian insufficiency: the context of long-term

effects." J Endocrinol Invest 39.9 (2016): 983-90. doi: 10.1007/

s40618-016-0467

34. Scarabin, P.Y., Oger, E., Plu-Bureau, G.

"Differential association of oral and transdermal oestrogen-

replacement therapy with venous thromboembolism risk." Lancet 362 (2003): 428-32.

35. Canonico, M., Oger, E., Plu-Bureau, G., et al.

"Hormone therapy and venous thromboembolism among postmenopausal women: impact of the route of estrogen administration and progestogens: the ESTHER study." Circulation 115 (2007): 840-84.

36. Sidney, S., Cheetham, T.C., Connell, F.A., et al.

"Recent combined hormonal contraceptives (CHCs) and the risk of thromboembolism and other cardiovascular events in new users." Contraception 87 (2013): 93-100

37. Langrish, J.P., Mills, N.L., Bath, L.E., et al.

"Cardiovascular effects of physiological and standard sex steroid

replacement regimens in premature ovarian failure." Hypertension 53 (2009): 805-11.

38. Bjarnason, K., Cerin, A., Lindgren, R., Weber, T., and Scandinavian Long Cycle Study Group.

"Adverse endometrial effects during long cycle hormone replacement therapy." Maturitas 32 (1999): 161-70.

39. Maciejewska-Jeske, M., Szeliga, A., Meczekalski, B.

"Consequences of premature ovarian insufficiency on women's sexual health."Prz Menopauzalny 17.3 (2018): 127-30. doi: 10.5114/

pm.2018.78557

40. Горбатюк, О.Г.

Оптимізація лікування вегето-судинних і психоневрологічних порушень клімактеричного синдрому / О.Г. Горбатюк,

А.П. Григоренко, А.С. Шатковська, В.Ю. Біньковська // Запорізький медичний журнал. - 2017. - Т. 19, № 4. - С. 482-486.

Gorbatiuk, O.G., Grigorenko, A.P., Shatkovska, A.S., Binkovska, V.Y.

"Optimization of treatment of vegetative-vascular and psychoneurological disorders of climacteric syndrome."Zaporizhzhya medical journal 19.4 (2017): 482-6.

41. Palma, F., Xholli, A., Cagnacci, A., as the writing group of the

AGATA study.

"Management of vaginal atrophy: a real mess. Results from the AGATA study." Gynecol Endocrinol 33 (2017): 702-7.

42. Yela, D.A. Soares, P.M. Benetti-Pinto, C

"Influence of Sexual Function on the Social Relations and Quality of Life of Women with Premature Ovarian Insufficiency." Rev Bras Ginecol Obstet 40 (2018): 66-71.

43. British Menopause Society (BMS)

Premature Menopause. BMS Council Consensus Statement (2007).

Available from: [http: // www.thebms.org.uk]

44. Tommaselli, G.A., Di Carlo, C., Di Spiezio Sardo, A., et al.

"Serum leptin levels and body composition in postmenopausal

women treated with tibolone and raloxifene." Menopause 13.4

(2006): $660-8$

45. Fagiolini, et al.

"Rediscovering Trazodone for the treatment of major depressive disorder." CNS Drugs 26 (2012): 1033-49.

46. Jankowska, K

"Premature ovarian failure." Menopause Rev 16.2 (2017): 51-6. 47. Simon, A., Laufer, $N$

"Repeated implantation failure: clinical approach." Fertil Steril 97 (2012): 1039-43

\section{PREMATURE OVARIAN INSUFFICIENCY - TO TREAT OR NOT TO TREAT?}

\section{Literature review}

0.S. Zahorodnia, MD, associate professor of the Obstetrics and Gynecology Department №1, 0.0. Bogomolets National Medical University, Kyiv

I.B. Ventskivska, MD, professor of the Obstetrics and Gynecology Department №1, 0.0. Bogomolets National Medical University, Kyiv

A.V. Kazak, PhD, associate professor of the Obstetrics and Gynecology Department №1, 0.0. Bogomolets National Medical University, Kyiv

Premature ovarian insufficiency (POI) is a rare but very damaging lifestyle condition that occurs at 1-1.5 of women and means termination of menstrual function up to 40 years old. POl impact on women's wellbeing includes lipid metabolism dysregulation, haemostasis regulation changes, both leading to heart diseases risk increasing, psychological problems, based on early reproductive function termination and anxiety because possible sexual dysfunction, manifestation of pelvic floor disorders. Patients with POl have symptoms, similar to women in menopause, namely vegetative nerve system disorders (hot flashes, night sweats, and emotional lability), insomnia and sexual dysfunction due to vaginal dryness, dyspareunia, and libido loss. It is believed, that estrogen and progesterone deficiency is a leading reason of these complains, but in the same time the role of testosterone decreasing concentration is discussed. Speaking accurately, therapy with exogenous estrogens for women with POl is really replacement, while for patients with normal age menopause it is rather therapy of extension. Nevertheless, only $52 \%$ patients with P0I have discussed it with their doctors.

The article deals with question hormone replacement therapy rationality from the point of view of most popular menopause disorders. Special trials for some of them are published, as for bone mineral density and sexual disorders, treatment for other is possible only by extrapolation from general cohort of menopausal women. For each position questions of effectiveness and safety is discussed. Different ways of estrogen administration are considered, as well as progestin variations. A special attention is paid to possibility of reproductive function restoration in patients with Pol. Non-hormonal methods of menopause symptoms correction also discussed - from life style modification to drug administration.

Keywords: premature ovarian insufficiency, replace hormone therapy, estrogens.

\section{ПЕРЕДЧАСНЕ ВИСНАЖЕННЯ ЯЕЧНИКІВ - ЛІКУВАТИ ЧИ НЕ ЛІКУВАТИ?}

\section{Огляд літератури}

О.С. Загородня, д. мед. Н., доцент кафедри акушерства та гінекології №1 Нму ім. О.0. Богомольця, м. Київ

І.Б. Венцківська, Д. мед. Н., професор, завідувачка кафедрою акушерства та гінекології №1 Нму ім. 0.0. Богомольця, м. Київ

А.В. Казак, К. мед. Н., доцент кафедри акушерства та гінекології №1 НМУ ім 0.0. Богомольця, м. Київ

Передчасне виснаження яєчників - стан досить рідкісний, проте йому властиве значне погіршення якості життя жінки. Він розвивається в 1-1,5\% жінок і 0значає припинення менструальної функції до 40 років. Вплив передчасного виснаження яєчників на здоров'я жінки включає порушення регуляції обміну ліпідів, зміни регуляції гемостазу, що призводить до збільшення ризику серцевих захворювань, психологічних проблем, обумовлених раннім припиненням репродуктивної функції та тривожністю, проявів порушень тазового дна. Пацієнтки з передчасним виснаженням яєчників мають симптоми, схожі на симптоми жіноку менопаузі, а саме: розлади вегетативної нервової системи (припливи жару, нічна пітливість, емоційна лабільність), безсоння та сексуальна дисфункція через сухість піхви, диспареунія та втрата лібідо. Вважається, що дефіцит естрогену і прогестерону є головною причиною цих скарг, але в той же час обговорюється роль зниження концентрації тестостерону. Відтак терапія екзогенними естрогенами для жінок із передчасним виснаженням яєчників справді є замісним лікуванням, тоді як для пацієнток із менопаузою, що настала за віком, це скоріше терапія розширення. Проте лише $52 \%$ пацієнток із раннім припиненням менструальної функції обговорюють дану проблему зі своїм лікарем.

У статті розглянуто питання раціональності замісної гормональної терапії з точки зору найбільш поширених менопаузальних проявів. Для деяких із них опубліковані спеціальні дослідження, наприклад, стосовно щільності кісткової тканини та сексуальних розладів, для інших оцінка ефективності лікування можлива лише на підставі екстраполяції даних загальної когорти жінок у менопаузі. Для кожної позиції обговорюються питання ефективності та безпеки. Розглянуто різні способи введення естрогенів, а також варіації гестагенів. Особлива увага приділена проблемі можливості відновлення репродуктивної функції в хворих із передчасним виснаженням яєчників. Також обговорюються негормональні методи корекції симптомів менопаузи - від зміни способу життя до прийому ліків.

Ключові слова: передчасна недостатність яєчників, замісна гормональна терапія, естрогени.

\section{ПРЕЖДЕВРЕМЕННОЕ ИСТОЩЕНИЕ ЯИЧНИКОВ - ЛЕЧИТЬ ИЛИ НЕ ЛЕЧИТЬ?}

\section{Обзор литературы}

А.С. Загородняя, д. мед. Н., доцент кафедры акушерства и гинекологии №1 нмУ им. А.А. Богомольца, г. Киев

И.Б. Венцковская, д. мед. Н., профессор, заведующая кафедрой акушерства и гинекологии №1 НмУ им. А.А. Богомольца, г. Киев

А.В. Казак, к. мед. Н., доцент кафедры акушерства и гинекологии №1 НМУ им. А.А. Богомольца, г. Киев

Преждевременное истощение яичников - состояние достаточно редкое, однако ему свойственно значительное ухудшение качества жизни женщины. Оно развивается у 1-1,5\% женщин и 0значает прекращение менструальной функции до 40 лет. Влияние преждевременного истощения яичников на здоровье женщины включает нарушение регуляции обмена липидов, изменение регуляции гемостаза, что приводит К увеличению риска сердечных заболеваний, психологическим проблемам, обусловленным ранним прекращением репродуктивной функции и тревожностью, проявлениям нарушений тазового дна. Пациентки с преждевременным истощением яичников имеют симптомы, похожие на симптомы женщин в менопаузе, а именно: нарушения вегетативной нервной системы (приливы жара, ночная потливость, эмоциональная лабильность), бессонница и сексуальная дисфункция из-за сухости влагалища, диспареуния и потеря либидо. (читается, что дефицит эстрогена и прогестерона является главной причиной этих жалоб, но в то же время обсуждается роль снижения концентрации тестостерона. Поэтому терапия экзогенными эстрогенами женщин с преждевременным истощением яичников действительно является заместительным лечением, тогда как для пациенток с менопаузой, наступившей по возрасту, это скорее терапия расширения. Тем не менее, только 52\% пациенток с ранним прекращением менструальной функции обсуждают данную проблему со Своим врачом.

В статье рассмотрен вопрос рациональности заместительной гормональной терапии с точки зрения наиболее распространенных менопаузальных проявлений. Для некоторых из них опубликованы специальные исследования, например, относительно плотности костной ткани и сексуальных расстройств, для других оценка эффективности лечения возможна только на основании экстраполяции данных общей когорты женщин в менопаузе. Для каждой позиции обсуждаются вопросы эффективности и безопасности. Рассмотрены различные способы введения эстрогенов, а также вариации гестагенов. Особое внимание уделено проблеме возможности восстановления репродуктивной функции у больных с преждевременным истощением яичников. Также обсуждаются негормональные методы коррекции симптомов менопаузы - от изменения образа жизни до приема лекарств. 